\title{
lon-exchange-resin-catalyzed adamantylation of phenol derivatives with adamantanols: Developing a clean process for synthesis of 2-(1-adamantyl)-4-bromophenol, a key intermediate of adapalene
}

\author{
Nan Wang, Ronghua Wang, Xia Shi and Gang Zou*
}

\section{Full Research Paper}

\section{Address:}

Department of Fine Chemicals, East China University of Science \&

Technology, Meilong Rd. 130, Shanghai, 200237, China. Fax:

86-21-64253881; Tel: 86-21-64252390

Email:

Gang Zou* - zougang@ecust.edu.cn

* Corresponding author

Keywords:

adamantylation; ion-exchange resin; phenol; recycling

\author{
Beilstein J. Org. Chem. 2012, 8, 227-233. \\ doi:10.3762/bjoc.8.23 \\ Received: 08 November 2011 \\ Accepted: 26 January 2012 \\ Published: 08 February 2012 \\ Associate Editor: J. Aubé \\ (c) 2012 Wang et al; licensee Beilstein-Institut. \\ License and terms: see end of document.
}

\begin{abstract}
A clean process has been developed for the synthesis of 2-adamantylphenol derivatives through adamantylation of substituted phenols with adamantanols catalyzed by commercially available and recyclable ion-exchange sulfonic acid resin in acetic acid. The sole byproduct of the adamantylation reaction, namely water, could be converted into the solvent acetic acid by addition of a slight excess of acetic anhydride during the work-up procedure, making the process waste-free except for regeneration of the ionexchange resin, and facilitating the recycling of the resin catalyst. The ion-exchange sulfonic acid resin catalyst could be readily recycled by filtration and directly reused at least ten times without a significant loss of activity. The key intermediate of adapalene, 2-(1-adamantyl)-4-bromophenol, could be produced by means of this waste-free process.
\end{abstract}

\section{Introduction}

$o$-Adamantylphenols and their derivatives are the key skeletons of synthetic retinoid analogues [1-9] and supporting ligands of many homogeneous transition-metal catalysts [10-14]. Introduction of an adamantyl group to the phenol ring has largely relied on acid-catalyzed Friedel-Crafts alkylation with haloadamantanes or adamantanols [1-9,15-19]. Compared with adamantylation by haloadamantanes, the alkylation employing adaman- tanols combined with mineral acids, such as concentrated $\mathrm{H}_{2} \mathrm{SO}_{4}$, ensures that the process affords adamantylphenols under milder conditions, and thus often with higher selectivities. However, the work-up procedure of mineral-acid-promoted reactions necessitates aqueous quenching and neutralization steps to remove the acids, resulting in enormous quantities of waste. For example, although the state-of-the-art process 
promoted by combination of concentrated $\mathrm{H}_{2} \mathrm{SO}_{4}$ and glacial acetic acid in $\mathrm{CH}_{2} \mathrm{Cl}_{2}$ was adapted [20-22], it was still found that at least $15 \mathrm{~kg}$ of waste water, besides solid waste such as $\mathrm{Na}_{2} \mathrm{SO}_{4}$ and $\mathrm{NaOAc}$, was generated per kilogram of 2-(1adamantyl)-4-bromophenol, simply in an effort to remove the acids from the reaction mixture by means of aqueous quenching and washing. Therefore, the development of alternative procedures that can reduce or eliminate the waste from the work-up procedure is highly needed. It was reported that adamantylation of aromatics promoted by strong organic acids, such as trifluoroacetic acid [18] and triflic acid [19], could circumvent the drawbacks associated with using concentrated $\mathrm{H}_{2} \mathrm{SO}_{4}$. However, these strong organic protic acids are expensive and volatile, and thus their recovery poses many difficulties.

Strongly acidic ion-exchange sulfonic acid resins have been extensively exploited as recyclable acid catalysts for organic syntheses in both laboratory and industry since they became commercially available [23-26]. The success of recyclable ionexchange resins as substitutes for mineral acids in organic syntheses prompted us to study the possibility of using acidic sulfonic acid resin as a recyclable catalyst in the adamantylation reaction of 4-bromophenol (1a) with 1-adamantanol (2a) to develop a clean process for the production of the key intermediate of adapalene, namely 2-(1-adamantyl)-4-bromophenol (3aa). Olah et al. [15] reported that amberlyst and nafion- $\mathrm{H}$ could effectively catalyze adamantylation of aromatics with 1-bromoadamantane similarly to organic sulfonic acids or their fluorinated analogues. However, due to the detrimental effects of water on the catalytic activity of the cation-exchange resin in Friedel-Crafts alkylation, there is, to the best of our knowledge, no report on cation-exchange-resin-catalyzed adamantylation of phenols with adamantanols, although alkylation with alcohols is greener than that with alkyl halides. Herein, we report a process catalyzed by a recyclable acidic resin for an efficient and clean adamantylation of phenol derivatives by using adamantanols [27].

\section{Results and Discussion}

Treatment of 4-bromophenol (1a) with 1.05 equiv of 1 -adamantanol (2a) in the presence of a macroporous sulfonic acid cation-exchange resin (Amberlite 200, $\mathrm{H}^{+}$form) in ethyl acetate or diethyl carbonate under reflux for 10-12 h gave the desired product 2-(1-adamantyl)-4-bromophenol (3aa) in good yields; however, no reaction occurred in acetonitrile under similar conditions (Table 1, entries 1-3). The reaction proceeded faster in 1,2-dichloroethane but with lower selectivity, generating some (9\%) doubly adamantylated product, 2,6-bis(1adamantyl)-4-bromophenol, (Table 1, entry 4).

The cation-exchange-resin catalyst could be easily recovered by filtration and washing with diethyl carbonate. However, the catalytic activity of the recovered resin catalyst strongly depended on the dryness of the resin. That is, the water byproduct had to be thoroughly removed from the recovered resin by drying the resin under vacuum $(<0.5 \mathrm{mmHg})$ at $90{ }^{\circ} \mathrm{C}$ for $3 \mathrm{~h}$ before reuse, otherwise the reaction could not be carried to completion even after heating under reflux for $24 \mathrm{~h}$ (Table 1,

\begin{tabular}{|c|c|c|c|c|c|}
\hline entry & resin loading $(g)^{b}$ & solvent & $T\left({ }^{\circ} \mathrm{C}\right)$ & $t(\mathrm{~h})$ & yield $(\%)^{\mathrm{C}}$ \\
\hline 1 & 1.0 & $\mathrm{CH}_{3} \mathrm{CO}_{2} \mathrm{Et}$ & reflux & 12 & 94 \\
\hline 2 & 1.0 & $\mathrm{CO}(\mathrm{OEt})_{2}$ & reflux & 10 & 96 \\
\hline 3 & 1.0 & $\mathrm{CH}_{3} \mathrm{CN}$ & reflux & 12 & trace \\
\hline 4 & 1.0 & $\left(\mathrm{CH}_{2} \mathrm{Cl}\right)_{2}$ & reflux & 5 & 83 \\
\hline 5 & $1.0,1^{\text {st }}$ recycle $^{d}$ & $\mathrm{CO}(\mathrm{OEt})_{2}$ & reflux & 24 & $76^{e}$ \\
\hline 6 & $1.0,2^{\text {nd }}$ recycle $^{f}$ & $\mathrm{CO}(\mathrm{OEt})_{2}$ & reflux & 15 & 93 \\
\hline 7 & $1.0,3^{\text {rd }}$ recycle $^{f}$ & $\mathrm{CO}(\mathrm{OEt})_{2}$ & reflux & 15 & 89 \\
\hline 8 & 1.0 & $\mathrm{EtOH}$ & reflux & 12 & trace \\
\hline 9 & 1.0 & $\mathrm{CH}_{3} \mathrm{CO}_{2} \mathrm{H}$ & 100 & 2 & 98 \\
\hline 10 & 1.0 & $\mathrm{CH}_{3} \mathrm{CO}_{2} \mathrm{H}$ & 60 & 12 & 75 \\
\hline 11 & 1.0 & $\mathrm{CH}_{3} \mathrm{CO}_{2} \mathrm{H}$ & 80 & 7 & 95 \\
\hline 12 & 0 & $\mathrm{CH}_{3} \mathrm{CO}_{2} \mathrm{H}$ & 100 & 6 & trace \\
\hline 13 & 0.30 & $\mathrm{CH}_{3} \mathrm{CO}_{2} \mathrm{H}$ & 100 & 6 & 92 \\
\hline 14 & 0.75 & $\mathrm{CH}_{3} \mathrm{CO}_{2} \mathrm{H}$ & 100 & 4 & 98 \\
\hline 15 & $0.75^{\mathrm{g}}$ & $\mathrm{CH}_{3} \mathrm{CO}_{2} \mathrm{H}$ & 100 & 18 & 85 \\
\hline
\end{tabular}

aThe reaction was run at $3 \mathrm{mmol}$ scale with respect to 4-bromophenol in air. ${ }^{b}$ Amberlite $200, \mathrm{H}^{+}$form used. Clsolated yields. ${ }^{\mathrm{d}}$ The recovered resin catalyst was dried in vacuum at $50{ }^{\circ} \mathrm{C}$ for $1 \mathrm{~h}$. ${ }^{\mathrm{e}} 14 \%$-bromophenol recovered. ${ }^{\mathrm{f}}$ The recovered resin catalyst was dried in vacuum at $90{ }^{\circ} \mathrm{C}$ for $3 \mathrm{~h}$. gAmberlite IR120 used instead of Amberlite 200. 
entries 5-7). To facilitate recycling of the resin catalyst, we tested the reaction in ethanol, which was supposed to help in removing the byproduct water from the resin, but no reaction was observed after $12 \mathrm{~h}$ under reflux. However, when the reaction was conducted in acetic acid at $100{ }^{\circ} \mathrm{C}$ (bath temperature), almost a quantitative yield of the target product 2-(1adamantyl)-4-bromophenol (3aa) was obtained (98\% after purification by chromatography) in $2 \mathrm{~h}$ (Table 1 , entry 9).

The control experiment showed that no reaction occurred in the absence of the acidic ion-exchange resin, clearly excluding the possibility of acetic acid catalysis in the adamantylation (Table 1, entry 12). When the loading of the resin catalyst was reduced to $0.3 \mathrm{~g}$ and $0.75 \mathrm{~g}$ from $1.0 \mathrm{~g}$, for $3 \mathrm{mmol}$ 4-bromophenol (1a), the adamantylation reaction still gave $92 \%$ and $98 \%$ yields of the target product, respectively, within 4-6 h (Table 1, entries 13 and 14). However, the microporous sulfonic acid cation-exchange resin (Amberlite IR120, $\mathrm{H}^{+}$form) was found to be less effective in promoting the adamantylation compared to the macroporous analogue. For example, the reaction took a longer time and still gave a lower yield with Amberlite IR120 (Table 1, entry 15).

Acetic acid appeared to be the best choice of solvent for the resin-catalyzed adamantylation with 1-adamantanol (2a), as it not only gave the desired 2-(1-adamantyl)-4-bromophenol (3aa) in high yields within a shorter reaction time, but it also made it possible to directly reuse the recovered resin catalyst since the byproduct, water, which is detrimental to the catalytic activity of such resins, could be easily converted into acetic acid by the addition of an equivalent amount of acetic anhydride during the work-up procedure. Further, after the sole byproduct, water, is converted into the solvent acetic acid, the resulting process is waste-free except for regeneration of the resin at its first use. Therefore, both the resin catalyst and the acetic acid solvent can be easily recovered by simple filtration and readily reused.

The recyclability of the acidic ion-exchange-resin catalyst was then investigated (Figure 1). To facilitate the operation, the reaction was run at $15 \mathrm{mmol}$ scale with respect to $1 \mathrm{a}$, with $5.0 \mathrm{~g}$ of the resin catalyst. When the reaction was completed, the mixture was cooled to $50-60{ }^{\circ} \mathrm{C}$, and an acetic acid solution containing 1.05 equiv acetic anhydride was added to the mixture in order to convert the byproduct, water, to the solvent, acetic acid, thereby realizing a waste-free process and removal of water from the resin in order to facilitate recycling of the resin catalyst. After being stirred for a while (1-2 h) to ensure complete consumption of water in the mixture, the resin catalyst was filtered, washed with acetic acid and used directly in the subsequent run. In fact, the resin catalyst, Amberlite 200, $\mathrm{H}^{+}$ form, was reused ten times without significant loss of activity in the reaction of 4-bromophenol (1a) with 1-adamantanol (2a) in acetic acid. Solvent acetic acid was recovered from the filtrate by distillation, and the residue, crude product 2-(1-adamantyl)4-bromophenol (3aa), was further purified by recrystallization in $\mathrm{CH}_{2} \mathrm{Cl}_{2}$ /petroleum ether.

The scope of the sulfonic acid resin catalyzed adamantylation of phenol derivatives with adamantanols was further explored (Table 2).

The reaction rate was slightly decreased by electron-withdrawing groups compared to 4-bromophenol (1a). For example, cresols (1c, 1d) and 4-chlorophenol (1b) reacted similarly to the model reaction of 4-bromophenol (1a), giving the monoadamantylation products $\mathbf{3 c a}, \mathbf{3 d a}$ and $\mathbf{3 b a}$ in good to excellent

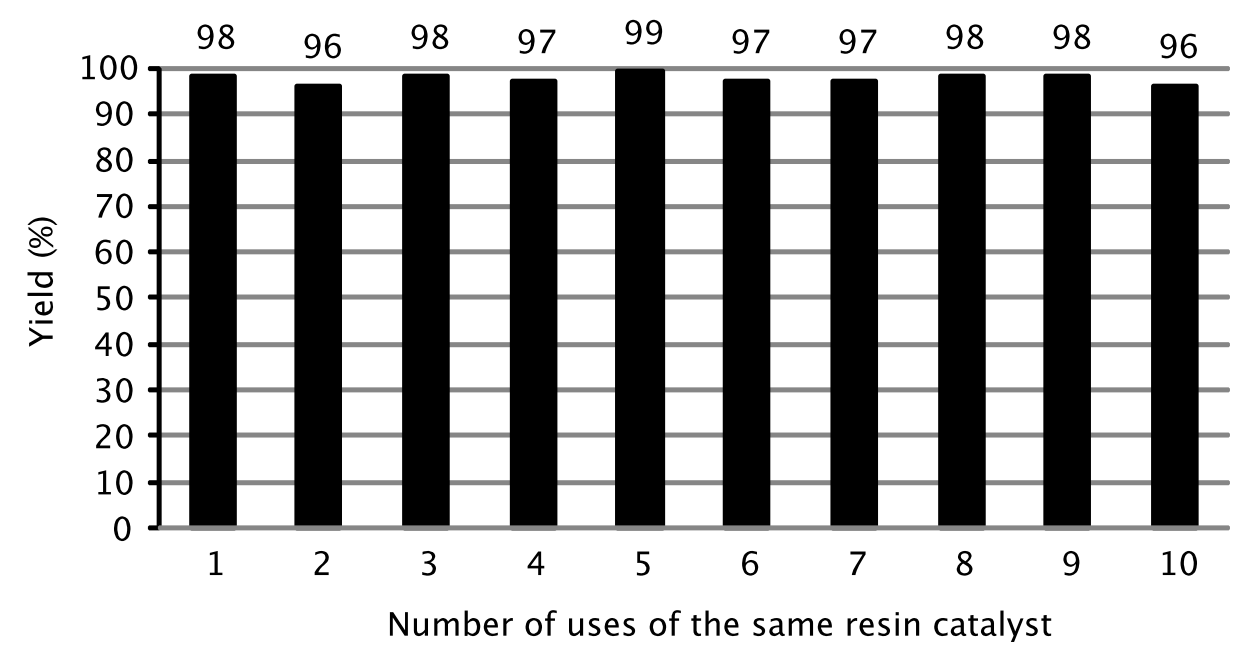

Figure 1: Recycling of the ion-exchange-resin catalyst in the adamantylation reaction of 4-bromophenol (1a) with 1-adamantanol (2a). 
Table 2: Scope of the ion-exchange-resin catalyzed adamantylation.

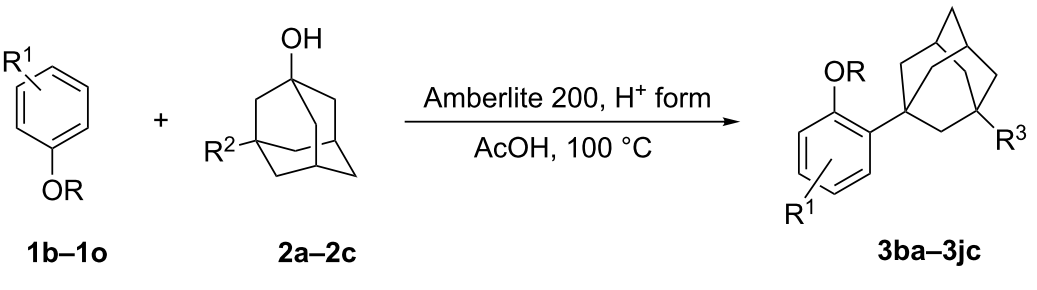

\begin{tabular}{|c|c|c|c|c|c|}
\hline entry & $\mathrm{R} / \mathrm{R}^{1}$ & $\mathrm{R}^{2}$ & $t(\mathrm{~h})$ & $\mathrm{R}^{3}$ & yield $(\%)^{\mathrm{a}}$ \\
\hline 1 & $\mathrm{H} / 4-\mathrm{Cl}(\mathbf{1 b})$ & $\mathrm{H}(\mathbf{2 a})$ & 2 & $\mathrm{H}(\mathbf{3} \mathbf{b a})$ & 90 \\
\hline 2 & $\mathrm{H} / 4-\mathrm{CH}_{3}(1 \mathrm{c})$ & $\mathrm{H}(\mathbf{2 a})$ & 2 & $\mathrm{H}(3 \mathbf{c a})$ & 87 \\
\hline 3 & $\mathrm{H} / 3-\mathrm{CH}_{3}(1 \mathrm{~d})$ & $\mathrm{H}(2 \mathrm{a})$ & 2 & $\mathrm{H}(3 \mathrm{da})$ & 94 \\
\hline 4 & H/4-OMe (1e) & $H(2 a)$ & 1 & $\mathrm{H}(3 \mathrm{ea})$ & $80^{b}$ \\
\hline 5 & $\mathrm{H} / 4-\mathrm{CHO}(\mathbf{1 f})$ & $\mathrm{H}(\mathbf{2 a})$ & 4 & $H(3 f a)$ & 84 \\
\hline 6 & $\mathrm{H} / 4-\mathrm{CO}_{2} \mathrm{Et}(\mathbf{1 g})$ & $H(2 a)$ & 4 & $H(3 g a)$ & 75 \\
\hline 7 & $\mathrm{H} / 4-\mathrm{CH}_{3} \mathrm{CO}(\mathbf{1 h})$ & $\mathrm{H}(\mathbf{2 a})$ & 10 & $\mathrm{H}$ (3ha) & 82 \\
\hline 8 & $\mathrm{H} / 4-\mathrm{NO}_{2}(1 \mathrm{i})$ & $\mathrm{H}(\mathbf{2 a})$ & 12 & $\mathrm{H}(\mathbf{3 i a})$ & 66 \\
\hline 9 & $\mathrm{Me} / 4-\mathrm{Br}(\mathbf{1 j})$ & $\mathrm{H}(\mathbf{2 a})$ & 7 & $\mathrm{H}(\mathbf{3} \mathbf{j a})$ & 80 \\
\hline 10 & $\mathrm{H} / \mathrm{H}(\mathbf{1 k})$ & $\mathrm{H}(\mathbf{2 a})$ & 4 & $\mathrm{H}(3 \mathbf{k} a)$ & $-^{\mathrm{c}}$ \\
\hline 11 & $\mathrm{H} / 4-\mathrm{Br}(\mathbf{1 a})$ & $\mathrm{COOH}(\mathbf{2 b})$ & 9 & $\mathrm{COOH}(3 \mathrm{ab})$ & 75 \\
\hline 12 & $\mathrm{H} / 4-\mathrm{Br}(\mathbf{1 a})$ & $\mathrm{CH}_{2} \mathrm{OH}(2 \mathrm{c})$ & 7 & $\mathrm{CH}_{2} \mathrm{OAc}(3 \mathrm{ac})$ & 90 \\
\hline 13 & $\mathrm{H} / 4-\mathrm{CH}_{3}(1 \mathrm{c})$ & $\mathrm{CH}_{2} \mathrm{OH}(2 \mathrm{c})$ & 4 & $\mathrm{CH}_{2} \mathrm{OAc}(3 \mathrm{cc})$ & 94 \\
\hline 14 & $\mathrm{Me} / 4-\mathrm{Br}(\mathbf{1 j})$ & $\mathrm{CH}_{2} \mathrm{OH}(2 \mathrm{c})$ & 7 & $\mathrm{CH}_{2} \mathrm{OAc}(3 \mathrm{jc})$ & 94 \\
\hline
\end{tabular}

aThe reaction was run at $1 \mathrm{mmol}$ scale with Amberlite $200, \mathrm{H}^{+}$form $(0.35 \mathrm{~g} / \mathrm{mmol}$ with respect to phenols $)$ in air. ${ }^{\mathrm{b}}$ The lower yield was partly due to crystallization to completely remove 3-(1-adamantyl)-4-methoxyphenol after chromatography. ${ }^{\mathrm{C}} \mathrm{A}$ mixture of isomers was formed.

yields and selectivities (Table 2, entries 1-3). No isomers of 3da, e.g., 2-(1-adamantyl)-3-methylphenol or 3-methyl-4-(1adamantyl)phenol, were observed for $\mathrm{m}$-cresol (1d). The reaction of phenols bearing an electron-withdrawing group, e.g., $-\mathrm{CHO}(\mathbf{1 f}),-\mathrm{COCH}_{3}(\mathbf{1 h}),-\mathrm{CO}_{2} \mathrm{Et}(\mathbf{1 g})$ and $-\mathrm{NO}_{2}(\mathbf{1 i})$, needed a longer time to afford the 2-adamantylation products in good yields (Table 2, entries 5-8). When 4-methoxyphenol (1e) was subjected to 2 a under similar conditions, both 2-(1-adamantyl)4-methoxyphenol (3ea) and its isomer 3-(1-adamantyl)-4methoxyphenol (3ea') formed in 9:1 molar ratio as determined by ${ }^{1} \mathrm{H}$ NMR analysis of the crude products, indicating that the hydroxy group $(-\mathrm{OH})$ favourably directed the adamantylation compared to the methoxy group (-OMe), although the reaction of 4-bromoanisole (1j) provided 2-(1-adamantyl)-4bromoanisole (3ja) as the solely isolated adamantylation product (Table 2, entries 4 and 9). However, phenol itself reacted to give a mixture of bi- and mono-adamantylphenol isomers, whereas 1,4-hydroquinone formed an insoluble solid material immediately upon being heated with sulfonic acid resin in acetic acid.

On the 1-adamantanol counterpart, the presence of the carboxyl acid group and the carbinol group appeared not to affect the adamantylation significantly. The reaction of 3-hydroxy-1- adamantanecarboxylic acid (2b) with 4-bromophenol (1a) gave the desired product $\mathbf{3 a b}$ in $75 \%$ yield (Table 2, entry 11). Interestingly, reactions of 3-hydroxymethyl-1-adamantanol (2c) with 4-bromophenol (1a), $p$-cresol (1c), or 4-bromoanisole (1j), afforded solely acetylated adamantylation products, 2-(3acetoxymethyl-1-adamantyl)-4-bromophenol (3ac), 2-(3acetoxymethyl-1-adamantyl)-p-cresol (3cc), or 2-(3acetoxymethyl-1-adamantyl)-4-bromoanisole (3je) in $90 \%$, $94 \%$ and $94 \%$ yields, respectively (Table 2 , entries $12-14$ ). That is, the carbinol group was completely acetylated under the reaction conditions. Moreover, no unacetylated product was detected during the monitoring of the reaction progress, implying that acetylation of carbinol proceeded faster than the adamantylation under these acidic conditions.

\section{Conclusion}

In summary, we have developed a clean process for the synthesis of 2-adamantylphenol derivatives in acetic acid using a commercially available, strongly acidic cross-linked polystyrene-type sulfonic acid resin as a recyclable catalyst. The features of this process include (a) an almost waste-free procedure, except for the regeneration of the resin catalyst at its first use, after conversion of the sole byproduct, water, to the solvent acetic acid by anhydride; (b) the acidic ion-exchange-resin cata- 
lyst could be readily separated from the products by simple filtration and directly reused at least ten times without any reactivation, whilst showing no significant loss of activity; (c) the technique is effective with a wide range of substituted phenols giving $o$-adamantylation products with respect to the $\mathrm{OH}$ group, in good to excellent yields with high selectivities. The key intermediate of adapalene, 2-(1-adamantyl)-4-bromophenol, was produced by this procedure in excellent yields under the optimized conditions.

\section{Experimental General}

Unless stated otherwise, all reagents and chemicals obtained commercially were used without further purification. Melting points are reported uncorrected and were recorded by using an electrothermal melting-point apparatus. ${ }^{1} \mathrm{H}$ and ${ }^{13} \mathrm{C}$ NMR spectra were recorded on a Bruker Avance Spectrometer. Massspectrum analysis was performed at the Center for Analysis, ECUST. 3-Hydroxyadamantane-1-carboxylic acid and 3-(hydroxymethyl)-1-adamantol were purchased from Alfa Aesar and Sigma-Aldrich, respectively.

\section{Regeneration of the sulfonic acid resins ( $\mathrm{H}^{+}$form)}

Sulfonic acid resins (Amberlite 200 and Amberlite-IR 120, Polysciences Inc.) were regenerated following a procedure reported in the literature [28]: $100 \mathrm{~g}$ of resin was stirred with $20 \%$ sulfuric acid $(500 \mathrm{~mL})$ overnight, then filtered and washed with deionized water until the washings reached a $\mathrm{pH}$ value of 5-6. The resin was then washed with THF $(2 \times 50 \mathrm{~mL})$, dried in vacuum at $90{ }^{\circ} \mathrm{C}$ for $2 \mathrm{~h}$, and kept over $\mathrm{P}_{2} \mathrm{O}_{5}$ in a vacuum desiccator.

\section{Representative procedure for the acidic-ion- exchange-resin-catalyzed adamantylation with resin recycling}

2-(1-Adamantyl)-4-bromophenol (3aa) [29]: To a suspension of dry sulfonic acid resin (Amberlite 200, $\mathrm{H}^{+}$form, $5.0 \mathrm{~g}$ ) in acetic acid (15 mL), adamantan-1-ol (2a; $2.43 \mathrm{~g}, 16 \mathrm{mmol})$ and $p$-bromophenol (1a; $2.60 \mathrm{~g}, 15 \mathrm{mmol})$ were added. The mixture was heated to $100{ }^{\circ} \mathrm{C}$ (bath temperature) and stirred for $2 \mathrm{~h}$. After being cooled to about $60^{\circ} \mathrm{C}$, acetic anhydride (1.61 g, 16 $\mathrm{mmol})$ in acetic acid $(5 \mathrm{~mL})$ was added to the reaction mixture and was stirred for $30 \mathrm{~min}$ followed by filtration in order to separate the resin catalyst from the solution. The resin was washed with acetic acid until it was free of product and was directly reused in the next run. The filtrate and the washings were combined, from which acetic acid was recovered by distillation, and the crude residue was purified by recrystallization from petroleum ether $/ \mathrm{CH}_{2} \mathrm{Cl}_{2}$ to afford 2-(1-adamantanyl)-4bromophenol (3aa) as a colourless fine crystals (4.48 g, 98\%); mp $146-148{ }^{\circ} \mathrm{C} ;{ }^{1} \mathrm{H}$ NMR $\left(400 \mathrm{MHz}, \mathrm{CDCl}_{3}, 25^{\circ} \mathrm{C}\right) \delta 7.29(\mathrm{~d}$, $J=2.8 \mathrm{~Hz}, 1 \mathrm{H}), 7.14\left(\mathrm{dd}, J_{1}=8.4 \mathrm{~Hz}, J_{2}=2.4 \mathrm{~Hz}, 1 \mathrm{H}\right), 6.52$ $(\mathrm{d}, J=8.4 \mathrm{~Hz}, 1 \mathrm{H}), 4.80(\mathrm{~s}, 1 \mathrm{H}, \mathrm{OH}), 2.08(\mathrm{~s}, 9 \mathrm{H}), 1.77(\mathrm{~s}, 6 \mathrm{H})$; ${ }^{13} \mathrm{C}$ NMR $\delta 153.54,138.78,130.24,129.34,118.40,113.26$, $40.30,36.94,28.95$.

\section{Representative procedure for ion-exchange- resin-catalyzed adamantylation on a small scale}

2-(1-Adamantyl)-4-chlorophenol (3ba): A mixture of adamantan-1-ol (2a; $0.160 \mathrm{~g}, 1.05 \mathrm{mmol})$, 4-chlorophenol (1c; $0.128 \mathrm{~g}, 1.0 \mathrm{mmol})$ and resin $(0.35 \mathrm{~g})$ was stirred at $90{ }^{\circ} \mathrm{C}$ for $2 \mathrm{~h}$ in acetic acid $(2 \mathrm{~mL})$. After the reaction was complete, the resin catalyst was filtered and washed with ethyl acetate. The solvents were removed from the combined filtrate to give the crude product, which was further purified by column chromatography (petroleum ether/ethyl acetate as eluent) to afford a white powder $(0.236 \mathrm{~g}, 90 \%)$; mp $139-141{ }^{\circ} \mathrm{C} ;{ }^{1} \mathrm{H}$ NMR $(500$ $\left.\mathrm{MHz}, \mathrm{CDCl}_{3}\right) \delta 7.15(\mathrm{~d}, J=3.5 \mathrm{~Hz}, 1 \mathrm{H}), 6.99\left(\mathrm{dd}, J_{1}=3.0 \mathrm{~Hz}\right.$, $\left.J_{2}=10.5 \mathrm{~Hz}, 1 \mathrm{H}\right), 6.53(\mathrm{~d}, J=10.5 \mathrm{~Hz}, 1 \mathrm{H}), 4.86(\mathrm{~s}, 1 \mathrm{H}), 2.07$ $(\mathrm{s}, 9 \mathrm{H}), 1.76(\mathrm{~s}, 6 \mathrm{H}) ;{ }^{13} \mathrm{C}$ NMR $\delta 153.05,138.30,127.36$, 126.32, 125.67, 117.87, 40.30, 36.95, 28.96; ESI-HRMS: $[\mathrm{M}-1]^{+}$calcd for $\mathrm{C}_{16} \mathrm{H}_{18} \mathrm{OCl}, 261.1052$; found 261.1046.

\section{Characterization data for the adamantylation products}

2-(1-Adamantyl)-4-methylphenol (3ca) [30]: $\mathrm{mp} 129-131{ }^{\circ} \mathrm{C}$; ${ }^{1} \mathrm{H} \mathrm{NMR}\left(400 \mathrm{MHz}, \mathrm{CDCl}_{3}, 25^{\circ} \mathrm{C}\right) \delta 7.06(\mathrm{~s}, 1 \mathrm{H}), 6.90(\mathrm{~d}, J=$ $7.6 \mathrm{~Hz}, 1 \mathrm{H}), 6.58(\mathrm{~d}, J=8.0 \mathrm{~Hz}, 1 \mathrm{H}), 4.68(\mathrm{~s}, 1 \mathrm{H}, \mathrm{OH}), 2.32(\mathrm{~s}$, $3 \mathrm{H}), 2.17(\mathrm{~s}, 6 \mathrm{H}), 2.12(\mathrm{~s}, 3 \mathrm{H}), 1.83(\mathrm{~s}, 6 \mathrm{H}) ;{ }^{13} \mathrm{C} \mathrm{NMR} \delta$ 152.18, 136.17, 129.71, 127.72, 127.03, 116.68, 40.63, 37.14, $36.61,29.12,20.88$.

2-(1-Adamantyl)-5-methylphenol (3da) [30]: mp 84-86 ${ }^{\circ} \mathrm{C}$; ${ }^{1} \mathrm{H}$ NMR (400 MHz, $\left.\mathrm{CDCl}_{3}\right) \delta 7.14(\mathrm{~d}, J=8.0 \mathrm{~Hz}, 1 \mathrm{H}), 6.76(\mathrm{~d}$, $J=8.0 \mathrm{~Hz}, 1 \mathrm{H}), 6.51(\mathrm{~s}, 1 \mathrm{H}), 4.85(\mathrm{~s}, 1 \mathrm{H}), 2.30(\mathrm{~s}, 3 \mathrm{H}), 2.16(\mathrm{~s}$, $6 \mathrm{H}), 2.12(\mathrm{~s}, 3 \mathrm{H}), 1.83(\mathrm{~s}, 6 \mathrm{H}) ;{ }^{13} \mathrm{C}$ NMR $\delta 154.25,136.71$, 133.57, 126.89, 121.48, 117.66, 40.78, 37.15, 36.39, 29.13, 20.60 .

3-(1-Adamantyl)-4-hydroxyanisole (3ea): White powder; mp 207-209 ${ }^{\circ} \mathrm{C}$; ${ }^{1} \mathrm{H}$ NMR $\left(500 \mathrm{MHz}, \mathrm{CDCl}_{3}\right) \delta 6.81(\mathrm{~s}, 1 \mathrm{H}), 6.59$ (br s, 2H), $4.62(\mathrm{~s}, 1 \mathrm{H}), 3.76(\mathrm{~s}, 3 \mathrm{H}), 2.11(\mathrm{~s}, 6 \mathrm{H}), 2.07(\mathrm{~s}, 3 \mathrm{H})$, $1.77(\mathrm{~s}, 6 \mathrm{H}) ;{ }^{13} \mathrm{C}$ NMR $\delta 153.57,148.62,137.86,117.05$, 113.95, 110.43, 55.71, 40.42, 37.04, 36.82, 29.04; ESI-HRMS: $[\mathrm{M}-1]^{+}$calcd for $\mathrm{C}_{17} \mathrm{H}_{21} \mathrm{O}_{2}, 257.1542$; found, 257.1538.

3-Adamantyl-4-hydroxybenzaldehyde (3fa) [31]: $\mathrm{mp}$ 217-219 ${ }^{\circ} \mathrm{C} ;{ }^{1} \mathrm{H}$ NMR $\left(400 \mathrm{MHz}, \mathrm{CDCl}_{3}\right) \delta 9.85(\mathrm{~s}, 1 \mathrm{H}), 7.79$ (s, 1H), 7.62 (d, $J=8.4 \mathrm{~Hz}, 1 \mathrm{H}), 6.79(\mathrm{~d}, J=8.0 \mathrm{~Hz}, 1 \mathrm{H}), 6.09$ $(\mathrm{s}, 1 \mathrm{H}), 2.14-2.10(\mathrm{~m}, 9 \mathrm{H}), 1.79(\mathrm{~s}, 6 \mathrm{H}) ;{ }^{13} \mathrm{C}$ NMR $\delta(125$ 
$\left.\mathrm{MHz}, \mathrm{C}_{5} \mathrm{D}_{5} \mathrm{~N}\right) \delta 191.71,164.37,138.12,130.79,129.92$, $129.80,117.89,40.87,37.70,29.82$.

2-(1-Adamantyl)-4-hydroxybenzoic acid ethyl ester (3ga): White powder; mp 250-252 ${ }^{\circ} \mathrm{C} ;{ }^{1} \mathrm{H}$ NMR $\left(500 \mathrm{MHz}, \mathrm{C}_{6} \mathrm{D}_{6} \mathrm{~N}\right) \delta$ $13.85(\mathrm{~s}, 1 \mathrm{H}), 9.80(\mathrm{~d}, J=3.0 \mathrm{~Hz}, 1 \mathrm{H}), 9.53\left(\mathrm{dd}, J_{1}=2.5 \mathrm{~Hz}, J_{2}\right.$ $=10.5 \mathrm{~Hz}, 1 \mathrm{H}), 8.66(\mathrm{~d}, J=10.0 \mathrm{~Hz}, 1 \mathrm{H}), 5.88(\mathrm{q}, J=9.0 \mathrm{~Hz}$, $2 \mathrm{H}), 3.85(\mathrm{~d}, J=2.5,6 \mathrm{H}), 3.54(\mathrm{~s}, 3 \mathrm{H}), 3.25(\mathrm{~m}, 6 \mathrm{H}), 2.78(\mathrm{t}, J$ $=9.0 \mathrm{~Hz}, 3 \mathrm{H}) ;{ }^{13} \mathrm{C}$ NMR $\delta 167.59,162.83,137.37,129.95$, 129.89, 122.07, 117.36, 61.00, 40.98, 37.71, 29.84, 15.08; ESI-HRMS: $[\mathrm{M}-1]^{+}$calcd for $\mathrm{C}_{19} \mathrm{H}_{23} \mathrm{O}_{3}, 299.1647$; found, 299.1648 .

3-(1-Adamantyl)-4-hydroxyacetophenone (3ha): White powder; mp $183-185{ }^{\circ} \mathrm{C} ;{ }^{1} \mathrm{H} \mathrm{NMR}\left(400 \mathrm{MHz}, \mathrm{CDCl}_{3}, 25{ }^{\circ} \mathrm{C}\right)$, $\delta 7.92(\mathrm{~d}, J=2.0 \mathrm{~Hz}, 1 \mathrm{H}), 7.74\left(\mathrm{dd}, J_{1}=8.4 \mathrm{~Hz}, J_{2}=2.0 \mathrm{~Hz}\right.$, $1 \mathrm{H}), 7.01(\mathrm{~s}, 1 \mathrm{H}), 6.80(\mathrm{~d}, J=8.4 \mathrm{~Hz}, 1 \mathrm{H}), 2.60(\mathrm{~s}, 3 \mathrm{H}), 2.16$, $2.10(\mathrm{~s}+\mathrm{s}$ overlapped, $9 \mathrm{H}), 1.80(\mathrm{~s}, 6 \mathrm{H}) ;{ }^{13} \mathrm{C}$ NMR $\delta(100$ $\left.\mathrm{MHz}, \mathrm{C}_{5} \mathrm{D}_{5} \mathrm{~N}, 25^{\circ} \mathrm{C}\right) \delta 197.09,163.02,137.39,129.90,129.35$, 128.59, 117.18, 41.01, 37.76, 29.89, 26.78; ESI-HRMS: $[\mathrm{M}-1]^{+}$calcd for $\mathrm{C}_{18} \mathrm{H}_{21} \mathrm{O}_{2}, 269.1542$; found, 269.1540.

2-(1-Adamantyl)-4-nitrophenol (3ia): White powder; $\mathrm{mp}$ $227-229{ }^{\circ} \mathrm{C} ;{ }^{1} \mathrm{H}$ NMR $\left(500 \mathrm{MHz}, \mathrm{C}_{6} \mathrm{D}_{6} \mathrm{~N}\right) \delta 8.29(\mathrm{~d}, J=3.5$ $\mathrm{Hz}, 1 \mathrm{H}), 8.10\left(\mathrm{dd}, J_{1}=3.5 \mathrm{~Hz}, J_{2}=11.0 \mathrm{~Hz}, 1 \mathrm{H}\right), 7.06(\mathrm{~d}, J=$ $11.5 \mathrm{~Hz}, 1 \mathrm{H}), 2.27(\mathrm{~s}, 6 \mathrm{H}), 2.06(\mathrm{~s}, 3 \mathrm{H}), 1.78(\mathrm{~m}, 6 \mathrm{H})$; ${ }^{13} \mathrm{C}$ NMR $\delta 164.76,141.08,138.14,124.20,124.16$ (overlapped with $\left.\mathrm{C}_{6} \mathrm{D}_{6} \mathrm{~N}\right), 117.31,40.60,37.81,37.57,29.74$; ESI-HRMS: [M - 1] $]^{+}$calcd for $\mathrm{C}_{16} \mathrm{H}_{18} \mathrm{NO}_{3}, 272.1287$; found, 272.1291 .

2-(1-Adamantyl)-4-bromoanisole (3ja) [29]: $\mathrm{mp} 136-138{ }^{\circ} \mathrm{C}$; ${ }^{1} \mathrm{H}$ NMR $\left(400 \mathrm{MHz}, \mathrm{CDCl}_{3}, 25^{\circ} \mathrm{C}\right) \delta 7.31(\mathrm{~s}, 1 \mathrm{H}), 7.28(\mathrm{~d}, J=$ $8.4 \mathrm{~Hz}, 1 \mathrm{H}), 6.75(\mathrm{~d}, J=8.8 \mathrm{~Hz}, 1 \mathrm{H}), 3.83(\mathrm{~s}, 3 \mathrm{H}), 2.08(\mathrm{~s}, 9 \mathrm{H})$, $1.79(\mathrm{~s}, 6 \mathrm{H}) ;{ }^{13} \mathrm{C}$ NMR $\delta 157.95,140.83,129.79,129.33$, $113.36,113.32,55.23,40.39,37.22,37.06,29.07$.

2-(3-Acetoxymethyl-1-adamantyl)-4-bromophenol (3ac): White powder; mp $184-186{ }^{\circ} \mathrm{C}$; ${ }^{1} \mathrm{H}$ NMR (400 MHz, DMSO$\left.d_{6}\right) \delta 9.65(\mathrm{~s}, 1 \mathrm{H}), 7.16\left(\mathrm{dd}, J_{1}=8.4 \mathrm{~Hz}, J_{2}=2.4 \mathrm{~Hz}, 1 \mathrm{H}\right), 7.11$ $(\mathrm{d}, J=2.4 \mathrm{~Hz}, 1 \mathrm{H}), 6.73(\mathrm{~d}, J=8.4 \mathrm{~Hz}, 1 \mathrm{H}), 3.69(\mathrm{~s}, 2 \mathrm{H}), 2.10$ (s, 2H), 2.01-1.94 (m, 7H), $1.80(\mathrm{~s}, 2 \mathrm{H}), 1.60-1.50(\mathrm{~m}, 2 \mathrm{H})$, $1.49(\mathrm{~m}, 4 \mathrm{H}) ;{ }^{13} \mathrm{C}$ NMR $\delta 170.38,155.38,137.47,129.14$, $128.80,118.32,110.38,72.89,40.99,39.04$ (overlapped with DMSO- $d_{6}$ ), 38.04, 36.62, 35.77, 33.69, 28.09, 20.57; ESI-HRMS: $[\mathrm{M}-1]^{+}$calcd for $\mathrm{C}_{19} \mathrm{H}_{22} \mathrm{BrO}_{3}, 377.0752$; found, 377.0756 .

2-(3-Acetoxymethyl-1-adamantyl)-4-methylphenol (3cc): White powder; mp $217-219{ }^{\circ} \mathrm{C}$; ${ }^{1} \mathrm{H}$ NMR (400 MHz, DMSO$\left.d_{6}\right) \delta 8.97(\mathrm{~s}, 1 \mathrm{H}), 6.85(\mathrm{~s}, 1 \mathrm{H}), 6.78(\mathrm{~d}, J=8.0 \mathrm{~Hz}, 1 \mathrm{H}), 6.63$ $(\mathrm{d}, J=8.0 \mathrm{~Hz}, 1 \mathrm{H}), 3.69(\mathrm{~s}, 2 \mathrm{H}), 2.17(\mathrm{~s}, 3 \mathrm{H}), 2.10(\mathrm{~s}, 2 \mathrm{H})$, 2.01-1.95 (m, 7H), $1.67(\mathrm{~s}, 2 \mathrm{H}), 1.65-1.55(\mathrm{~m}, 2 \mathrm{H}), 1.50$ (br s, $4 \mathrm{H}) ;{ }^{13} \mathrm{C}$ NMR $\delta 170.46,153.58,134.47,126.84,126.75$, $126.69,116.14,73.02,41.38,39.30$ (overlapped with DMSO$\left.d_{6}\right), 38.20,36.26,35.95,33.71,28.19,20.60$; ESI-HRMS: $[\mathrm{M}-1]^{+}$calcd for $\mathrm{C}_{20} \mathrm{H}_{25} \mathrm{O}_{3}, 313.1804$; found, 313.1798.

2-(3-Acetoxymethyl-1-adamantyl)-4-bromoanisole (3jc): White powder; mp $110-112{ }^{\circ} \mathrm{C} ;{ }^{1} \mathrm{H}$ NMR (400 MHz, $\left.\mathrm{CDCl}_{3}\right) \delta$ $7.27(\mathrm{~d}, J=9.6 \mathrm{~Hz}, 1 \mathrm{H}), 7.26(\mathrm{~s}, 1 \mathrm{H}), 6.73(\mathrm{~d}, J=9.2 \mathrm{~Hz}, 1 \mathrm{H})$, $3.80(\mathrm{~s}, 3 \mathrm{H}), 3.74(\mathrm{~s}, 2 \mathrm{H}), 2.16(\mathrm{~s}, 2 \mathrm{H}), 2.06(\mathrm{~s}, 3 \mathrm{H}), 2.00-1.95$ (m, 4H), 1.83 (s, 2H), 1.75-1.65 (m, 2H), 1.55 (br s, 4H); ${ }^{13} \mathrm{C}$ NMR $\delta 171.32,157.82,139.86,129.68,129.56,113.40$, 113.28, 73.92, 55.21, 41.78, 39.78, 38.61, 37.44, 36.31, 34.09, 28.75, 20.91; ESI-HRMS: $[\mathrm{M}]^{+}$calcd for $\mathrm{C}_{20} \mathrm{H}_{25} \mathrm{BrO}_{3}$, 392.0987; found, 392.0984 .

2-(3-Carboxy-1-adamantyl)-4-bromophenol (3ab): White powder; mp 209-211 ${ }^{\circ} \mathrm{C} ;{ }^{1} \mathrm{H}$ NMR (400 MHz, DMSO- $\left.d_{6}\right) \delta$ 12.02 (br s, 1H), 9.68 (br s, 1H), 7.17 (d, $J=8.0 \mathrm{~Hz}, 1 \mathrm{H}), 7.11$ (s, 1H), $6.74(\mathrm{~d}, J=8.4 \mathrm{~Hz}, 1 \mathrm{H}), 2.11-2.01(\mathrm{~m}, 4 \mathrm{H}), 1.95-1.92$ $(\mathrm{m}, 4 \mathrm{H}), 1.80(\mathrm{~s}, 4 \mathrm{H}), 1.66(\mathrm{~s}, 2 \mathrm{H}) ;{ }^{13} \mathrm{C}$ NMR $\delta 178.36,155.37$, $137.28,129.25,128.78,118.37,110.42,40.56,40.51$ (overlapped with DMSO- $d_{6}$ ), 38.62, 37.90, 36.57, 35.41, 28.11; ESI-HRMS: $[\mathrm{M}-1]^{+}$calcd for $\mathrm{C}_{17} \mathrm{H}_{18} \mathrm{BrO}_{3}, 349.0439$; found, 349.0440 .

\section{Acknowledgements}

Financial support provided by the National Science Foundation of China (20972049) is gratefully acknowledged.

\section{References}

1. Shroot, B.; Eustache, J.; Bernardon, J.-M. Benzonaphthalene derivatives and compositions. U.S. Patent 4,717,720, Jan 5, 1988.

2. Dawson, M. I.; Harris, D. L.; Liu, G.; Hobbs, P. D.; Lange, C. W.; Jong, L.; Bruey-Sedano, N.; James, S. Y.; Zhang, X.-k.; Peterson, V. J.; Leid, M.; Farhana, L.; Rishi, A. K.; Fontana, J. A J. Med. Chem. 2004, 47, 3518-3536. doi:10.1021/jm030524k

3. Cincinelli, R.; Dallavalle, S.; Nannei, R.; Carella, S.; de Zani, D.; Merlini, L.; Penco, S.; Garattini, E.; Giannini, G.; Pisano, C.; Vesci, L.; Carminati, P.; Zuco, V.; Zanchi, C.; Zunino, F. J. Med. Chem. 2005, 48, 4931-4946. doi:10.1021/jm049440h

4. Lorenzo, P.; Alvarez, R.; Ortiz, M. A.; Alvarez, S.; Piedrafita, F. J.; de Lera, Á. R. J. Med. Chem. 2008, 51, 5431-5440. doi:10.1021/jm800285f

5. Pérez-Rodríguez, S.; Ortiz, M. A.; Pereira, R.; Rodríguez-Barrios, F.; de Lera, Á. R.; Piedrafita, F. J. Eur. J. Med. Chem. 2009, 44, 2434-2446. doi:10.1016/j.ejmech.2009.01.011

6. Dawson, M. I.; Xia, Z.; Jiang, T.; Ye, M.; Fontana, J. A.; Farhana, L.; Patel, B.; Xue, L. P.; Bhuiyan, M.; Pellicciari, R.; Macchiarulo, A.; Nuti, R.; Zhang, X.-K.; Han, Y.-H.; Tautz, L.; Hobbs, P. D.; Jong, L.; Waleh, N.; Chao, W.; Feng, G.-S.; Pang, Y.; Su, Y. J. Med. Chem. 2008, 51, 5650-5662. doi:10.1021/jm800456k 
7. Cincinelli, R.; Dallavalle, S.; Nannei, R.; Merlini, L.; Penco, S.; Giannini, G.; Pisano, C.; Vesci, L.; Ferrara, F. F.; Zuco, V.; Zanchi, C.; Zunino, F. Bioorg. Med. Chem. 2007, 15, 4863-4875. doi:10.1016/j.bmc.2007.04.057

8. Dawson, M. I.; Xia, Z.; Liu, G.; Fontana, J. A.; Farhana, L.; Patel, B. B.; Arumugarajah, S.; Bhuiyan, M.; Zhang, X.-K.; Han, Y.-H.; Stallcup, W. B.; Fukushi, J.-i.; Mustelin, T.; Tautz, L.; Su, Y.; Harris, D. L.; Waleh, N.; Hobbs, P. D.; Jong, L.; Chao, W.-r.; Schiff, L. J.; Sani, B. P. J. Med. Chem. 2007, 50, 2622-2639. doi:10.1021/jm0613323

9. Tribulovich, V. G.; Garabadzhiu, A. V.; Kalvin'sh, I. Pharm. Chem. J. 2011, 45, 241-244. doi:10.1007/s11094-011-0605-z

10. Alexander, J. B.; Schrock, R. R.; Davis, W. M.; Hultzsch, K. C.; Hoveyda, A. H.; Houser, J. H. Organometallics 2000, 19, 3700-3715. doi:10.1021/om000336h

11. Gademann, K.; Chavez, D. E.; Jacobsen, E. N. Angew. Chem., Int. Ed. 2002, 41, 3059-3061. doi:10.1002/1521-3773(20020816)41:16<3059::AID-ANIE3059>3.0.CO ;2-I

12. Golisz, S. R.; Bercaw, J. E. Macromolecules 2009, 42, 8751-8762. doi:10.1021/ma901659q

13. Waltman, A. W.; Grubbs, R. H. Organometallics 2004, 23, 3105-3107. doi:10.1021/om049727c

14. Watanabe, T.; Ishida, Y.; Matsuo, T.; Kawaguchi, H. Dalton Trans. 2010, 39, 484-491. doi:10.1039/b911082h

15. Olah, G. A.; Török, B.; Shamma, T.; Török, M.; Prakash, G. K. S. Catal. Lett. 1996, 42, 5-13. doi:10.1007/BF00814460

16. Prakash, G. K. S.; Yan, P.; Tórók, B.; Bucsi, I.; Tanaka, M.; Olah, G. A. Catal. Lett. 2003, 85, 1-6. doi:10.1023/A:1022133227407

17. Shokova, E. A.; Khomich, A. N.; Kovalev, V. V. Tetrahedron Lett. 1996, 37, 543-546. doi:10.1016/0040-4039(95)02236-8

18. Stepakov, A. V.; Molchanov, A. P.; Kostikov, R. R. Russ. J. Org. Chem. 2007, 43, 538-543. doi:10.1134/S1070428007040082

19. Laali, K. K.; Sarca, V. D.; Okazaki, T.; Brock, A.; Der, P. Org. Biomol. Chem. 2005, 3, 1034-1042. doi:10.1039/b416997b

20. Pilgrim, W. R.; Lagiere, J. Process for the preparation of 1-adamantane derivatives. U.S. Patent 5,015,758, May 14, 1991

21. Cincinelli, R.; Dallavalle, S.; Merlini, L.; Penco, S.; Pisano, C.; Carminati, P.; Giannini, G.; Vesci, L.; Gaetano, C.; Illy, B.; Zuco, V.; Supino, R.; Zunino, F. J. Med. Chem. 2003, 46, 909-912. doi:10.1021/jm025593y

22. Liu, Z.; Xiang, J. Org. Process Res. Dev. 2006, 10, 285-288. doi:10.1021/op050223f

23. Gelbard, G. Ind. Eng. Chem. Res. 2005, 44, 8468-8498. doi:10.1021/ie0580405 And references therein.

24. Harmer, M. A.; Sun, Q. Appl. Catal., A 2001, 221, 45-62. doi:10.1016/S0926-860X(01)00794-3

25. Corain, B.; Zecca, M.; Jeřábek, K. J. Mol. Catal. A: Chem. 2001, 177, 3-20. doi:10.1016/S1381-1169(01)00305-3

26. Alexandratos, S. D. Ind. Eng. Chem. Res. 2009, 48, 388-398. doi:10.1021/ie801242v

27. Zou, G.; Wang, N.; Wang, R. Method for preparing 2-(1-adamantyl)-4-bromophenol. Chinese Patent CN101955417A, Jan 26,2011

28. Satyamurthy, N.; Barrio, J. R. J. Org. Chem. 1983, 48, 4394-4396. doi:10.1021/jo00171a050

29. Charpentier, B.; Bernardon, J.-M.; Eustache, J.; Millois, C.; Martin, B.; Michel, S.; Shroot, B. J. Med. Chem. 1995, 38, 4993-5006. doi:10.1021/jm00026a006
30. Aigami, K.; Inamoto, Y.; Takaishi, N.; Hattori, K.; Takatsuki, A.; Tamura, G. J. Med. Chem. 1975, 18, 713-721. doi:10.1021/jm00241a015

31. Brenna, E.; Fuganti, C.; Fronza, G.; Gatti, F. G.; Sala, F.; Serra, S Tetrahedron 2007, 63, 2351-2356. doi:10.1016/j.tet.2006.12.038

\section{License and Terms}

This is an Open Access article under the terms of the Creative Commons Attribution License

(http://creativecommons.org/licenses/by/2.0), which permits unrestricted use, distribution, and reproduction in any medium, provided the original work is properly cited.

The license is subject to the Beilstein Journal of Organic Chemistry terms and conditions:

(http://www.beilstein-journals.org/bjoc)

The definitive version of this article is the electronic one which can be found at: doi:10.3762/bjoc. 8.23 